\title{
A Study on Soil Stabilization Using Rbi Grade 81
}

\author{
Alaka Sreedhar ${ }^{1}$, Girish Mailar $^{2}$ \\ ${ }^{I}$ Assistant Professor, Department of Civil, CMR Institute of Technology, INDIA \\ ${ }^{2} \mathrm{HOD}$, Department of Civil, KaravalliInstitute of Technology, INDIA
}

\begin{abstract}
In the field of Construction expansive soils pose a great problem especially for foundations, \& using the locally available in situ soils is a big issue since they are not suitable for Construction. The most problematic soil in the field of Construction is the Black Cotton soil especially in foundations, since Black Cotton soil has a tendency to shrink and swell excessively. When it comes in contact with water, it swells and when it becomes dry it shrinks. The alternateprocess of swelling and shrinking results in differential settlement which results in Cracks in the building.Hence the entire in - situ soil is to be replaced which is a very complicated process. This can be avoided by conducting soil stabilization by making use of RBI Grade 81 powder.RBI Grade 81 is a Cementitious powder stabilizer which can be mixed in proper proportions to achieve desired results.Here I have conducted Modified Proctor Test on Black Cotton soil in the following proportions 1\%, 2\%, 4\%, 6\% and obtained results for Optimum Moisture Content and Maximum Dry density.Optimum moisture content increases as the percentage of stabilizer is increased and Maximum dry density decreases.

By making use of RBI Grade 81 stabilizer, excellent load bearing capacity is obtained.
\end{abstract}

Keywords: Black Cotton soil, Load bearing Capacity, Maximum dry density, Modified proctor test,Optimum Moisture Content, RBI Grade 81, Soil stabilization.

\section{Introduction}

In the developing Countries like India the most bothering issue during road construction is making use of locally available soil effectively, whatever the available soil may be, it cannot be used for roadway construction because of its low engineering properties \& feature. [7]Hence for enhancing its engineering properties, nowadays this kind of soils will be cured by making use of few of the stabilizers like lime Class $\mathrm{C}$ Fly ash, Portland bond, Pond Ash \& RBI Grade 81 for enhancing the engineering properties.[5]

\section{Soil Stabilization}

Soil Stabilization can be definedas any physical, chemical, biological or a combined method of changing the available natural soil in order to meet the engineering properties \& fulfill the necessity.[1], [5], [6], [11] Soil stabilization is a group of earth work technology which enhances the soil characteristics in order to improve mechanical \& load bearing properties through technological methods like Soil improvement \& Soil Consolidation Soil stabilization method is suitable for heavily soaked soils, which is not suitable for road or traffic construction since required rate of compaction cannot be achieved.[11], [12] The main resolution of soil stabilization is to progress the California bearing ratio of the available soil by four to six times \& to improve on site materials which in turn creates a solid \& a strong base \& sub base courses.[2]

\section{RBI GRADE 81:}

RBI Grade 81 can be expanded as Road Building International Grade 81 . It is a major material which was created for altering the various types of soil through an inexpensive approach. RBI Grade 81 is an ecofriendly, inorganic, hydration activated powder based stabilizer which combines along with the soil particles to create layers that are interconnected through a complex bury atom structure.[6], [10], [11], [12] It is a road construction material patented worldwide $\&$ in India. .It is a Cementitious power stabilizer which is grey in color, non-flammable \& also acts as waste binding. It modifies the engineering properties of soil by providing rapid infrastructure development. .A Company called Legend Developers in New Delhi supplies RBI Grade 81 (Road Building International Grade 81). The company has the license to manufacture it and has patented it. The product has recently been accredited by Central Road Research Institute, New Delhi. A combination of naturally occurring compounds form RBI Grade 81.Developed Countries like Germany, South Africa, Italy, Spainetc makes use of RBI Grade 81 to a great extent.[8] Hence "It is defined as an inorganic chemical stabilizer which modifies the engineering properties of soil." 


\section{Literature Review}

K.V. Madurwar. [12] rolled out a try to improve properties of black cotton soil with RBI-81 and sodium silicate. After then Atterberg limit, CBR and UCS test were directed out on the sample of soil with RBI-81 in extent of $2 \% \& 6 \%$ with curing time of $7,14 \& 28$ days. Which at long last made them to reach the conclusion that the ordinary soil which was having $2.33 \%$ CBR \& $2.69 \%$ UCS has been expanded to $10.03 \%$ \& $3.62 \%$ at 14 days adding so as to cure $2 \%$ RBI- $81 \& 8.03 \% \& 2.97 \%$ with 7 days curing. After then creators expanded the rate of RBI- 81 from $2 \%$ to $4 \%$ which gave them consequence of $18.87 \%$ \& $4.44 \%$ with 14 days curing and $16.24 \%$ \& $3.96 \%$ with 7 days curing. General the last conclusion which has been made by them was that the UCS \& CBR quality increments with expansion in RBI 81. Expansion proposes its dependability as great stabilizer to enhance execution of delicate soil. They likewise arrived at the conclusion that free swell index diminishes as RBI - 81 expanded and its goes on expanded by expansion in sodium silicate.

B.M.Patil[14] Manages the change in properties of sub grade soil by using soil stabilizer and provincially available poor materials. Where they completed standard proctor test on treated and untreated soil test and estimation of MDD and OMC were discover. The soil was treated with moorum and RBI 81 with distinctive extents tried for drenched CBR quality, MDD and OMC which came about for blend of soil: RBI Grade 81 in the extent of 100:0, 98:2, 96:4 the soaked CBR values are observed to be $2.56 \%, 4.89 \%$, and $8.79 \%$ and for blend of soil: moorum: RBI Grade 81 in the extent of 100:0:0, 90:10:0, 80:20:0, the soaked CBR qualities are observed to be $2.56 \%, 2.41 \%$ and $2.84 \%$ and for blend of soil: moorum: RBI Grade 81 , the extent of 78:20:2, 76:20:4 the splashed CBR qualities are observed to be $4.56 \%, 14.76 \%$ separately. This shows that the CBR value of sub grade soil can improved by using moorum along RBI 81 and development expense can be reduced to definite limit.

\section{Objectives}

RBI Grade 81 fulfills almost all the conditions for a well-proven, dependable \& an inexpensive way by forming a solid \& unalterable impervious film which shows resistance to any sort of climate, it may be a very high temperature or at even deep freezing conditions, \& it is also suitable for any vehicular loads. It is ecofriendly \& stresses on the usage of recycled material, noticing the shortage of resource availability.The aim of the project is making use of RBI Grade 81 as a replacement to Cement in the pavement construction after increasing its strength, stability and durability by the method of stabilization using RBI grade 81.Traditionally soil, stone aggregates, sand, bitumen, cement etc. are used in the construction of road. Resources are getting exhausted in nature, its capacity is also reducing slowly. Large quantity of soil is utilized in the road construction but enough quantity of soil of particular quality is not available easily. Hence huge number of trees is cut off resulting in deforestation, soil erosion \& loss of fertile soil which hinders the agricultural productivity. Even, cost of extracting goods, quality of natural material is increasing. Due to this reason, the scientists were in search of alternative materials for highway construction, and industrial waste product. If these materials are used correctly for road construction, the pollution and disposal problems can be solved up to some extent. Stabilization is the method used in this project to increase the inherent strength This will save the natural soil in addition to addressing the disposal.

\section{Necessity To Replace In - Situ Soil Can Be Eliminated:}

RBI Grade 81 can stabilize soil of any sort, either very sandy, very clayey, through which necessary replacement of in - situ materials can be avoided. Through this soil exchange can be avoided, and also reduction of the quantity of aggregate can be achieved, it also cuts down the expenditure during highway construction to a large extent when compared with other traditional ways.

PROPERTIES OF RBI GRADE 81:[3], [4], [6], [9], [10], [11]

General Properties: [14]

$>$ Cementitious Powder stabilizer

$>$ Non toxic

\section{Physical Properties:}

\begin{tabular}{|l|l|l|}
\hline Serial no & Physical properties & RBI Grade 81 \\
\hline 1 & Odor & Odorless \\
\hline 2 & Ph. & 12.5 \\
\hline 3 & Freezing point & None \\
\hline 4 & Flammability & Non-flammable \\
\hline 5 & Shelf life & 1 year \\
\hline 6 & Storage & Dry storage \\
\hline 7 & Bulk Density & $700 \mathrm{Kg} / \mathrm{m}^{3}$ \\
\hline
\end{tabular}




\begin{tabular}{|l|l|l|}
\hline 8 & Appearance & Greyish powder \\
\hline 9 & Specific Gravity & 2.5 \\
\hline 10 & Solubility & In water 0.2 pts/100pts \\
\hline 11 & Storage & $\begin{array}{l}\text { Store in dry place } \\
\text { avoiding contact of } \\
\text { moisture }\end{array}$ \\
\hline
\end{tabular}

Chemical Properties:

\begin{tabular}{|c|c|c|}
\hline Serial no & Chemical Properties & \% By mass \\
\hline 1 & Calcium & $\begin{array}{ll}\text { Calcium oxide } & 52-56 \%\end{array}$ \\
\hline 2 & Silicon & Silicon di oxide $\quad 15-19 \%$ \\
\hline 3 & Sulphur & Sulphur trioxide $\quad 9-11 \%$ \\
\hline 4 & Aluminum & Aluminum trioxide $5-7 \%$ \\
\hline 5 & Iron & Ferrous trioxide $0-2 \%$ \\
\hline 6 & Magnesium & Magnesium oxide $\quad 0-1 \%$ \\
\hline 7 & Manganese, Potassium, Copper, Zinc & $0.1-0.3 \%$ \\
\hline 8 & Water & $1-3 \%$ \\
\hline 9 & Fibers & $0-1 \%$ \\
\hline 10 & Additives & $0-4 \%$ \\
\hline
\end{tabular}

ADVANTAGES:[7], [8], [9]

- It is cost effective

- This stabilizer enhances engineering properties of soil

- No maintenance is necessary

- Suitable for all soil types

- Increase in load bearing capacity

- Water content is optimum

- Homogeneous mix can be achieved.

- RBI Grade 81 eliminates the necessity of soil materials

- Productivity Savings

- Materials like Aggregates/Good soil \& bitumen can be saved.

- Durability is increased.

- Strength is increased drastically

- Through stabilization water proofing of soil is achieved.

- Thickness is reduced.

- Transportation costs \& earth moving equipment's cost can be reduced.

- Duration of construction is reduced.

ENVIRONMENTAL CONSIDERATIONS:[7] [8], [9]

- It is environmental friendly which avoids the exhaustion of naturally available resources.

- Can be used in any weather conditions

- Saving of few major natural resources.

- weather resistance is increased

- Consumption of energy is minimized

- Reduces Carbon emission enabling, Carbon credits.

Problem Context:

- Conventional materials are limited in use as well as in applications.

- Conventional materials are not suitable for all types of soils

- Conventional materials are highly expensive.

- In situ soil is to be replaced.

- Soil exchange is require in conventional road construction

- It has got a negative impact on environment.

- Conventional methods of construction requiresmaintenance for whole life.

- Expansive soils like lateritic soils black cotton soils are problematic soils. 


\section{The Science \& Methodology:}

The technology is suitable for any type of soil, eliminating the concept of soil exchange usually related with traditional methods. These materials are restricted in its usage and quite expensive.[4],[5],[7], [11], [13] Methodology includes the basic \& introductory tests like Sieve tests, humidity Tests, specific gravity, and Atterberg limits and also the engineering property tests like CBR, UCT \& Tests for unstabilized\& stabilized soils which are performed based on the procedures mentioned in the prescribed IS codes [11], [13]. Some of the tests performed on these soils:-

$>$ Basic test for black cotton soil, red soil and

For Black Cotton soil+ RBI 81, red soil+ RBI 81

$>\mathrm{CBR}$ tests to find out CBR value and Unconfined Compressive Test for both uncured and 0, 3, days cured specimens, results discussed

\section{Study Of Properties Of Some Expansive Soils:}

Black cotton soil \& Lateritic soils are considered as a problematic soil by engineers all over the world. These soils cause damages to the structures as well as roads. The above mentioned expansive soils is like a challenge for engineers \& in the construction world. In order to utilize these soils for required purpose a proper treatment is to be given. This can be achieved by adding this stabilizer which enhances the properties of Black cotton soil \& Lateritic soils.[4], [5], [7], [10], [12], [13] Lateritic soil is combined of fine particles like medium \& fine sand, silt \&clay.[12]Based on the type of project experiments \& tests are done in field as well as in lab. After these tests problems \& issues can be identified \& solution can be found.[12], [13] One of the solutions will be in the form of stabilization of soils through which required type \& grade of material can be obtained.

Soil stabilization are of two types

- Mechanical Stabilization

- Chemical Stabilization

\section{Mechanical Stabilization:}

It is a method of mixing of different grades of soil in order to achieve a required particular grade of soil.[3] Chemical Stabilization:

It is a method of mixing the naturally available soil with suitable chemical agents in order to obtain required results. Few chemical agents are Portland cement, Asphalt binders, lime \& RBI Grade 81.RBI Grade 81 is supplemented by checking it clearly so that no dampness should be there. The addition should be from the range of $1 \%-2 \%$. Considerable amount of changes can be seen on the nature of the samples taken.[3]

\section{Black Cotton Soil:}

Black Cotton soil is a blackish grey inorganic clayey soil of medium elasticity.[10]

Properties Of Black Cotton Soil: [9], [10]

\begin{tabular}{|l|l|l|}
\hline Serial no & Property & IS Code \\
\hline 1 & Specific Gravity & 2.7 \\
\hline 2 & Natural Moisture content (\%) & 13.25 \\
\hline 3 & Liquid limit (\%) & 49.4 \\
\hline 4 & Plastic limit (\%) & 28.78 \\
\hline 5 & Shrinkage limit (\%) & 14.05 \\
\hline 6 & Plasticity index & 20.7 \\
\hline 7 & Grain size distribution (\%) & \\
\hline a) & Gravel & 8 \\
\hline b) & Sand & 20 \\
\hline c) & Silt \& Clay & 72 \\
\hline 8 & Free swell index (\%) & 27.27 \\
\hline 9 & Swelling Pressure Kn/m ${ }^{2}$ & 118 \\
\hline 10 & Optimum moisture content & 16.5 \\
\hline 11 & Maximum dry density Kn/m ${ }^{3}$ & 18.05 \\
\hline 12 & California bearing ratio & 2.55 \\
\hline 13 & Unconfined compressive strength $\left(\mathrm{Kn} / \mathrm{m}^{2}\right)$ & 133 \\
\hline 14 & Modulus of elasticity $(\mathrm{E}) \mathrm{Kn} / \mathrm{m}^{2}$ & 3924 \\
\hline
\end{tabular}

Table Properties of BC Soil

As we increase the proportions RBI Grade 81 powder liquid limit decreases when it is combined with soil, where as in plastic limit when RBI Grade 81 is mixed with soil, plastic limit increases when the proportions are increased.[11] 
When untreated BC soil was mixed with both RBI Grade $81 \&$ fly ash soaked CBR value was increase for RBI Grade 81 than for the fly ash \& there was a great improvement on the chemical properties of the soil treated with RBI Grade 81 than that of the fly ash.As the proportion of RBI Grade 81 is increased the soaked CBR value also increases \& it also enhances the behavior of soft soils.[1], [3], [5], [10]

\section{Modified Proctor Compaction Test:}

The Modified Proctor Compaction test for determining the OMC for the available type of soil will get denser \&attain MDD. To determine the relationship between optimum moisture content \& maximum dry density using Modified Proctor Compaction test The stabilizer was added to BC soil at different percentages. The results of modified proctor tests after addition of RBI Grade 81 when tested in lab is shown in the below table.

\begin{tabular}{|l|l|l|l|l|}
\hline Soil samples & Material ratio of untreated Black cotton sample & OMC in \% & MDD in Kn/m \\
\hline & Soil & Stabilizer & & \\
\hline Sample 0 & Untreated Black cotton soil & - & 16.6 & 18.25 \\
\hline Sample 1 & 99 & $1 \%$ & 17.13 & 18.13 \\
\hline Sample 2 & 98 & $2 \%$ & 17.4 & 17.70 \\
\hline Sample 3 & 96 & $4 \%$ & 17.86 & 17.43 \\
\hline Sample 4 & 94 & $6 \%$ & 18.32 & 17.22 \\
\hline
\end{tabular}

Table: Modified proctor compaction test results

\section{Result \&Discussions}

The black cotton soil was collected from site in Shimoga for testing purpose, the collected soil was equally partitioned into 5samples. For eachof them the RBI Grade 81 stabilizer is added in different percentages except for sample 0 since the sample 0 is an untreated black cotton soil for which no stabilizer is added. In sample 1 the ratio of RBI Grade 81 stabilizer \& soil is $1: 99$, for sample 2 the ratio is $2: 98$, for sample 3 the ratio is $4: 96 \&$ for sample 4 the ratio is $6: 94$. The results of optimum moisture content for sample 0 is 16.6 , after the supplementation of stabilizer, hence optimum moisture content raises as the $\%$ of stabilizer is raised \& with different percentages maximum dry density goes on decreasing with increased percentage of RBI Grade 81 stabilizer which is obtained after conducting the laboratory tests using Modified Proctor Compaction equipment. After the compaction the effects of RBI Grade $81 \&$ lime are similar which in turn results in cat - ion exchange process between RBI Grade $81 \&$ causes thickness reduction of diffuse double layer due to the reason that cat ions attract negatively charged clay particles. We get to know about this when liquid limit and plasticity values are achieved from the results when we conduct the test.

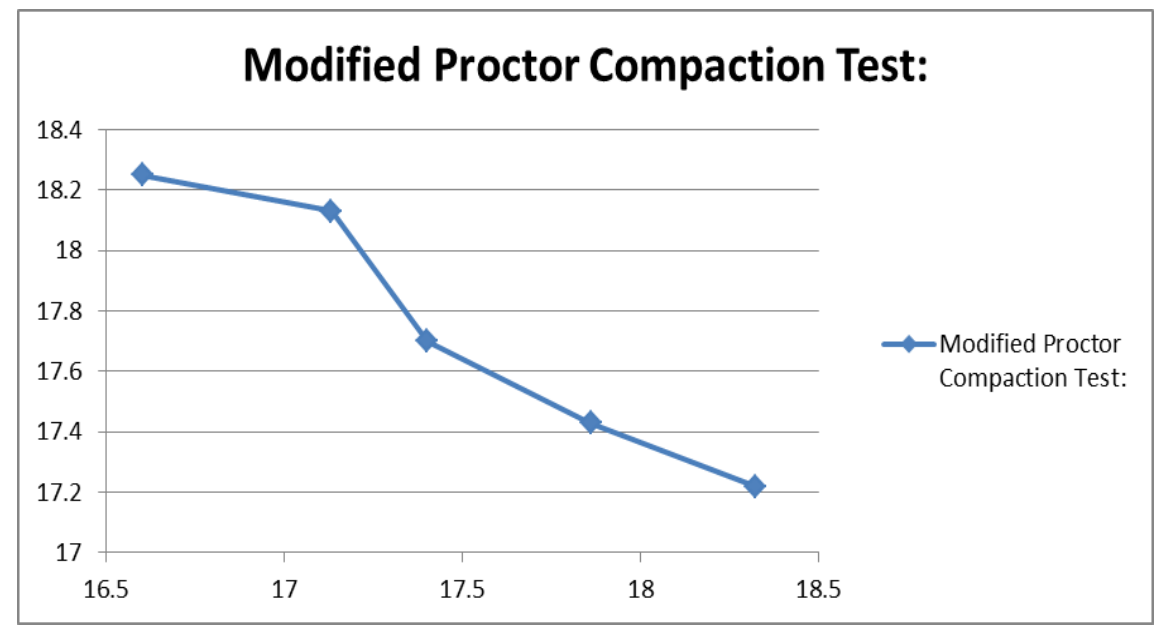

Graph 1: Modified proctor compaction test

We can find the change in result comprising of low compressibility \& a strong bond which is caused because of particle attraction. Therefore we can find increase in values of maximum dry density. This flocculated structure is of lighter weight which possess more water content $\&$ a high void ratio. Hence the value of optimum moisture content raises lightly when RBI Grade 81 stabilizer is being added. After this, the soil which is in the form of a gluey substance quite tough for compacting changes into a rigid substance that can be compacted easily resulting in a good load bearing capacity. 
Atterberg Limits:

Soil sample

\begin{tabular}{|l|l|l|l|l|}
\hline Soil sample & \%age of stabilizer & Liquid limit \% & Plastic limit \% & Plasticity Index \% \\
\hline Sample 0 & 0 & 49.07 & 28.74 & 20.33 \\
\hline Sample 1 & 1 & 48.13 & 29.52 & 18.61 \\
\hline Sample 2 & 2 & 46.70 & 30.21 & 16.49 \\
\hline Sample 3 & 4 & 44.60 & 32.24 & 12.36 \\
\hline Sample 4 & 6 & 43.15 & 33.02 & 10.13 \\
\hline Sample 5 & 8 & 42.63 & 34.67 & 7.96 \\
\hline
\end{tabular}

Table Plastic Limit results

\section{Discussion}

The Black cotton soil was collected at nearby place in shimoga. By varying the percentage of stabilizer of $1 \%, 2 \%, 4 \%, 6 \% \& 8 \%$ was performed on black cotton soil in order to determine Liquid limit \& Plastic limits by conducting Atterberg tests. On adding stabilizer there will be a decrease in LL \& PL. Properties in the treated mixture changes in plasticity which is subjected to cat - ion exchange, flocculation \& also agglomeration

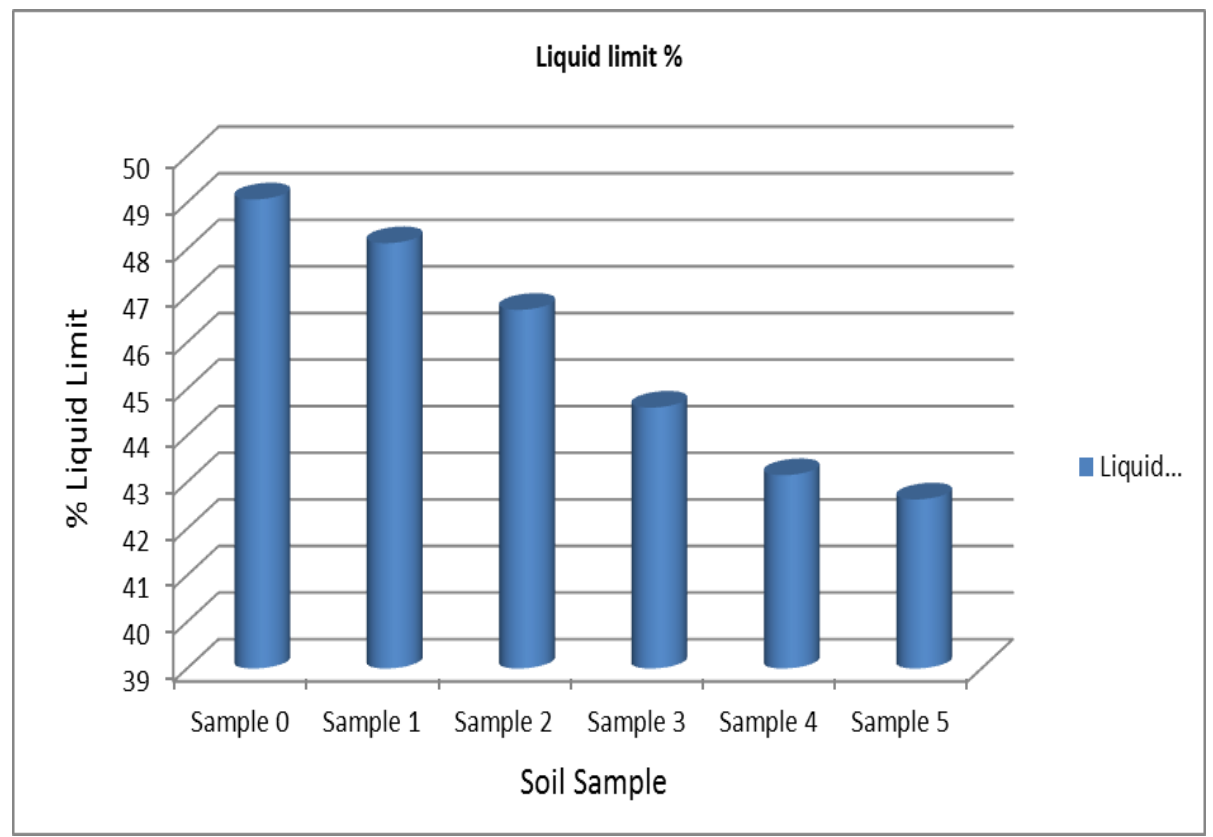

Graph 2: Liquid limit

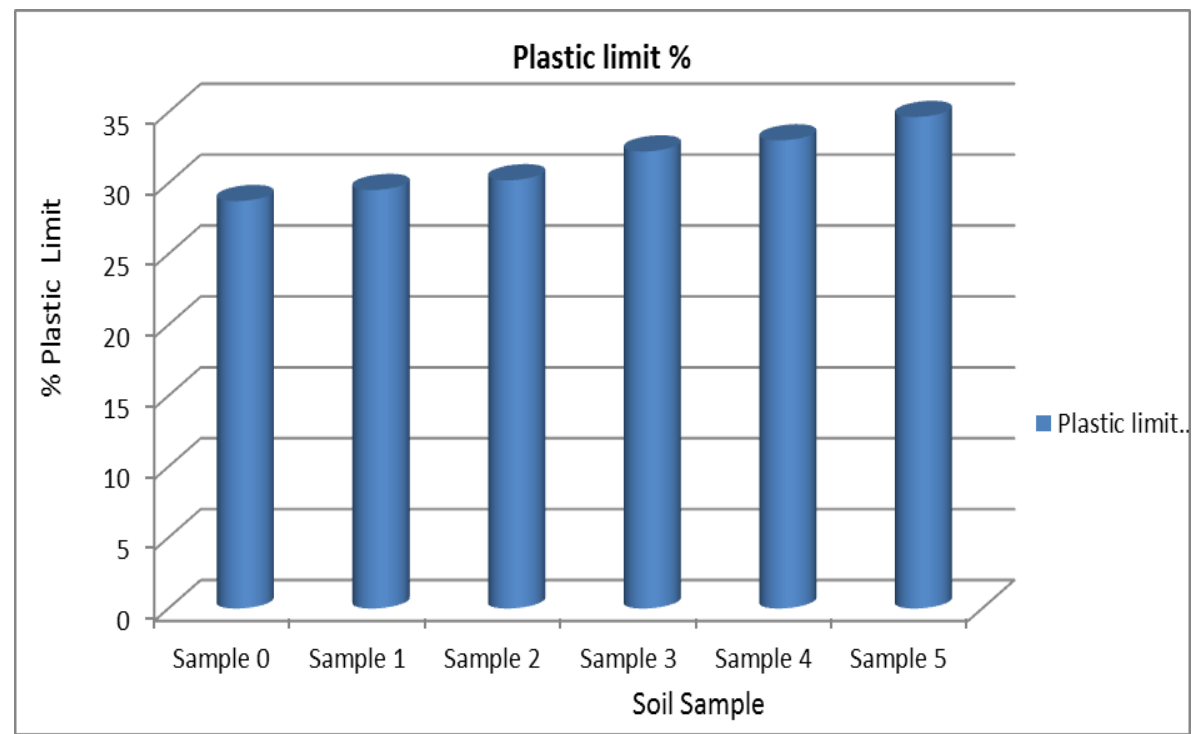

Graph 3: Plastic limit 


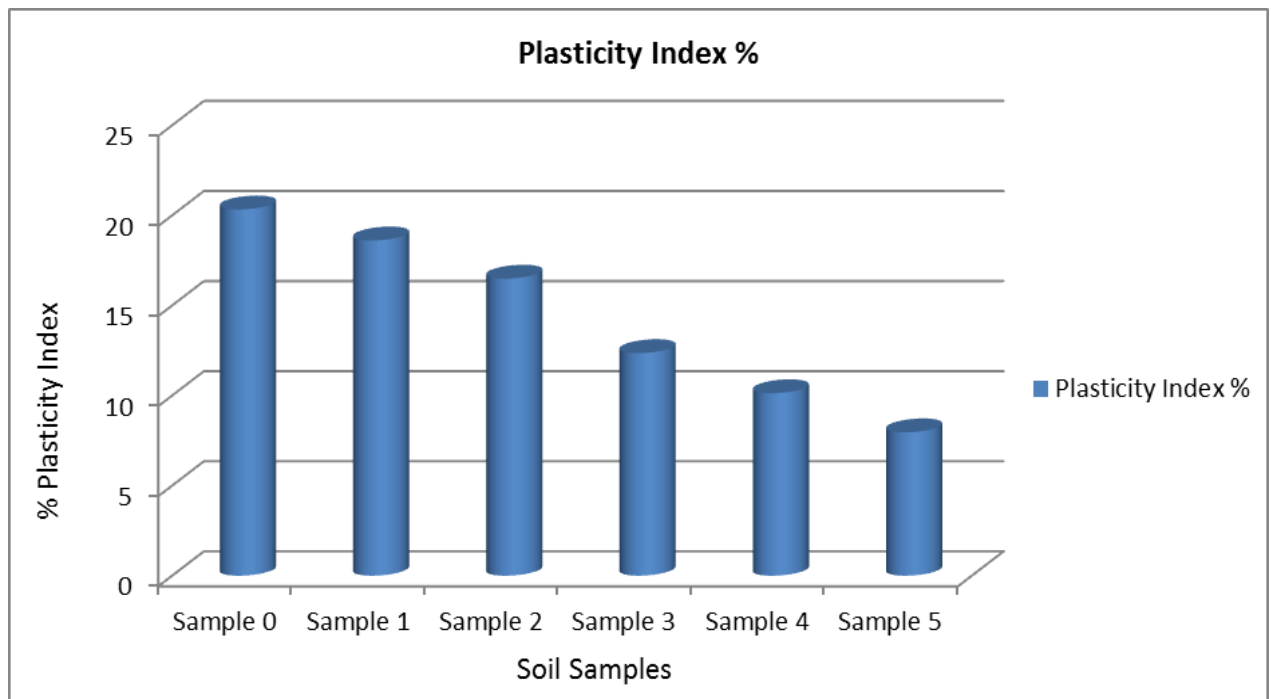

Graph 4: Plasticity index

\section{Applications}

- $\quad$ Parking \& Hard standing

- Military\& Paramilitary

- Advance Landing Ground

- Heliports

- Hard Standing Grounds

- Highways

- High Altitude Roads[3,5,8]

\section{Conclusions}

1. When the dosage of stabilizer is increased there is a drastic change optimum moisture content as well as maximum dry density.

2. By adding RBI Grade 81 stabilizer the geotechnical properties of Clayey soil is enhanced to a great extent.

3. Swelling property of Clay type soil is decreased by using this product.

4. Naturally available Granular material can be saved by using locally available Clayey soils.

5. Mainly we can conclude that RBI Grade 81 is suitable for any type of soils \& also it can be concluded that CBR value varies based on soil texture.

6. When BC soil is cured by $6 \%$ of RBI there will be a significant improvement of strength.

\section{References}

[1] J. Sudheer Kumar, Upma Janewoo, International Journal of Innovative Research in Science, Engineering and Technology (An ISO 3297: 2007 Certified Organization) Vol. 4, Issue 5, May 2015

[2] Avinash, N., Vinay, H., Prasad, D., Dinesh, S., and Dattatreya, J. (2014) Performance Evaluation of Low Volume Flexible Pavements - A Case Study. T\&DI Congress 2014: pp. 69-78.doi: 10.1061/9780784413586.007

[3] B.M.Patil, K.A.Patil, "Improvement in properties of Sub grade Soil by Using Moorum and RBI Grade 81", International Journal of Scientific \& Engineering Research, ISSN 2229-5518, Vol- 4, Issue- 5, May 2013.

[4] K.V. Madurwar, P.P. Dahale, A.N.Burile, "Comparative Study of Black Cotton Soil Stabilization with RBI Grade 81 and Sodium Silicate", International Journal of Innovative Research in Science, Engineering and Technology, ISSN: 2319-8753, Vol. -2, Issue 2, February 2013.

[5] Tejinder Singh, NavjotRiar, "Strengthening Of Sub grade By Using RBI Grade-81", IOSR Journal of Mechanical and Civil Engineering (IOSRJMCE) eISSN: 2278-1684, p-ISSN:

[6] B.M.Patil, K.A.Patil, "Effect of Fly Ash and RBI Grade 81 on Swelling Characteristics of Clayey Soil", International Journal of Advanced Technology In Civil Engineering, ISSN: 2231 - 5721, Volume-2, Issue-2, 2013

[7] Anitha.K.R, R.Ashalatha, ArveeSujil, Johnson," Effects of RBI Grade 81 on different types of sub grade soil”, 10th National Conference on Technological Trends, Nov 2009.

[8] VenuGopal.N; (2009), "Study Of Soil Properties With Silica fume As Stabilizer and Comparing the same With Rbi81 And Cost Estimation" Post Graduate Diploma Thesis, Visvesvaraya Technological University, Belgaum.

[9] Prof. S.S Razvi, ShaikhMustaqueem Ahmed, Syed Rehan Ahmed, Pathan Sultan Khaja, Sagar G. Daud, Jayant A. Patil "Study On Stabilization Of Soil Using Rbi Grade 81", International Journal of Innovative Research in Advanced Engineering (IJIRAE) ISSN: 2349-2163 Issue 5, Volume 2 (May 2015) 
[10] B. Vishnuvardhan Kumar1, M. Teja, G. Kalyan Kumar, "COMPARATIVE STUDIES OF BLACK COTTON SOIL WITH RBI GRADE 81 AND GROUND GRANULATED BLAST FURNACE SLAG”, 50th INDIAN GEOTECHNICAL CONFERENCE 17th - 19th DECEMBER 2015, Pune, Maharashtra, India Venue: College of Engineering (Estd. 1854), Pune, India.

[11] Lekha B.M, A.U. Ravi Shankar, "Laboratory Performance of RBI 81 Stabilized Soil for Pavements", International Journal of Civil Engineering Research. ISSN 2278-3652 Volume 5, Number 2 (2014), pp. 105-110 @ Research India Publications http://www.ripublication.com/ijcer.html.

[12] NajiaNouf, SurekaNaagesh, "EFFECT OF RBI-81 ON PROPERTIES OF BLACK COTTON SOIL", International Journal of Recent Development in Engineering and Technology Website: www.ijrdet.com (ISSN 2347 - 6435 (Online)) Volume No., Issue No., Month 2014)

[13] Mamta, Mallikarjun.Honna, "USING RBI GRADE 81 A COMPARATIVE STUDY OF BLACK COTTON SOIL AND LATERITIC SOIL", IJRET: International Journal of Research in Engineering and Technology eISSN: 23191163 | pISSN: 2321-7308

[14] BibhaMahto, A.K Duggal, “A REVIEW PAPER ON IMPROVEMENT OF SUBGRADE BY RBI GRADE 81 AND POND ASH”, International Research Journal of Engineering and Technology (IRJET) e-ISSN: 2395 -0056 Volume: 02 Issue: 05 | August-2015 www.irjet.net p-ISSN: 2395-0072.
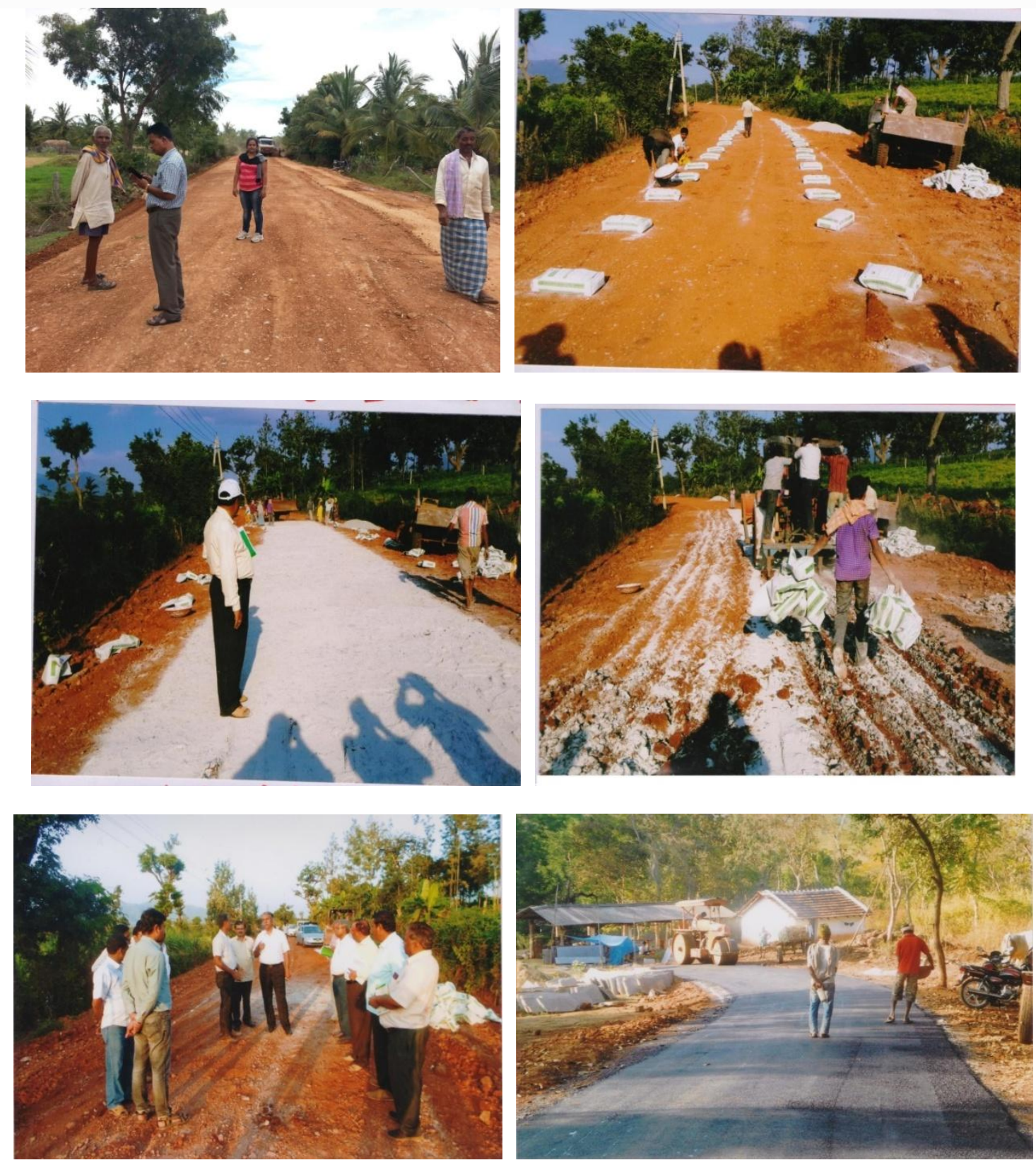